\title{
Performance, Adaptability and Stability of Soybean Cultivars Submitted to Different Environments Conditions
}

\author{
Carlos André Bahry (Corresponding author) \\ Universidade Tecnológica Federal do Paraná, Programa de Pós-Graduação em \\ Agroecossistemas. Estrada para Boa Esperança, km 04, s/n, Comunidade de São Cristóvão, \\ Dois Vizinhos, Paraná, Brazil. 85.660-000. \\ Tel: (+55) (046) 3536-8446 E-mail: carlosbahry@utfpr.edu.br
}

\section{Leandro André Petkowicz}

Universidade Tecnológica Federal do Paraná, Curso de Agronomia. Estrada para Boa Esperança, km 04, s/n, Comunidade de São Cristóvão, Dois Vizinhos, Paraná, Brazil. 85.660-000.

Tel: (+55) (046) 3536-8446 ～E-mail: leandro-pet@ hotmail.com

\section{Maicon Nardino}

${ }^{3}$ Universidade Federal de Viçosa, Departamento de Agronomia. Casa Diogo Alves de Melo, Avenida P. H. Rolfs, s/n, Campus Universitário, Viçosa, Minas Gerais, Brazil. 36.570-900., Tel: (+55) (031) 3612-4940 E-mail: nardinomn@ gmail.com.

\section{Ângela Aparecida Carleso}

Universidade Tecnológica Federal do Paraná, Programa de Pós-Graduação em Agroecossistemas. Estrada para Boa Esperança, km 04, s/n, Comunidade de São Cristóvão, Dois Vizinhos, Paraná, Brazil. 85.660-000.

Tel: (+55) (046) 3536-8446 ～E-mail: angelacarleso14@gmail.com

\section{Adriano Brutscher}

Universidade Tecnológica Federal do Paraná, Curso de Agronomia. Estrada para Boa Esperança, km 04, s/n, Comunidade de São Cristóvão, Dois Vizinhos, Paraná, Brazil. 85.660-000. 


\section{Macrothink Institute ${ }^{\mathrm{TM}}$}

Tel: (+55) (046) 3536-8446
Journal of Agricultural Studies

ISSN 2166-0379

2020, Vol. 8, No. 4

E-mail: adrianobrutscher00@hotmail.com

\title{
Josieli Aparecida da Silva
}

Universidade Tecnológica Federal do Paraná, Curso de Agronomia. Estrada para Boa Esperança, km 04, s/n, Comunidade de São Cristóvão, Dois Vizinhos, Paraná, Brazil. 85.660-000.

Tel: (+55) (046) 3536-8446

E-mail: josieliaparecidadasilva@gmail.com

\section{Paulo Fernando Adami}

Universidade Tecnológica Federal do Paraná, Programa de Pós-Graduação em Agroecossistemas. Estrada para Boa Esperança, km 04, s/n, Comunidade de São Cristóvão, Dois Vizinhos, Paraná, Brazil. 85.660-000.

Tel: (+55) (046) 3536-8446_～E-mail: pauloadami@utfpr.edu.br

Received: July 15, 2020

doi:10.5296/jas.v8i4.17352
Accepted: August 28, 2020

Published: Sep. 2, 2020

URL: https://doi.org/10.5296/jas.v8i4.17352

\begin{abstract}
For the plant breeding, developing a single soybean cultivar that is adapted and stable to multiple production environments has been a major challenge. Therefore, integrating the individual analysis of cultivars to their average response when gathered in groups of relative maturity can be a smart alternative to minimize risks and maximize soybean productivity. Nine soybean cultivars were grouped into four distinct groups as to their relative maturity (from 4.8 to 6.4), and tested in three sowing times (September, October and December) and three growing seasons (2016/17, 2017/18 and 2018/19) as to their yield performance, adaptability and stability in southwest Paraná, Brazil, latitude 25\%41'52 "S, longitude 5303'94" We, altitude of 509 meters. Performance was evaluated by grouping means, using Scott Knott. For the adaptability and stability analysis, AMMI (Additive Main effect and Multiplicative Interaction), GGE Biplot and Centroid methods were used. The NS 5909 IPRO® and NS 6909 IPRO® cultivars, both close to GMR 6.0, presented superior average performance in most of the evaluated production environments, and the earliest cultivars, with GMR less than 5.4, were the ones that produced less, in general, in different environments. Specific adaptations stood out from the general broad adaptation for the evaluated cultivars. The adaptability of the genotypes was not accompanied by high stability, which contributes to the reduction of the average productivity of the cultivars when exposed to different environments.
\end{abstract}


Keywords: Glycine max, grain yield, relative maturity group, genotype-environment interaction

\section{Introduction}

In order to be successful with soybean cultivation in countries that have a wide diversity of edaphoclimatic conditions, it is necessary to conduct research by adaptation zones, testing more suitable sowing times for cultivars of different relative maturity groups (RMG). With this, it is possible to reduce the risks inherent to its cultivation throughout the crop years (Carvalho et al., 2010).

The soybean is a thermo-photoperiodic crop in which high temperatures and short photoperiod accelerate the development of plants influencing their size and cycle and, consequently, the productive potential of the crop (Braccini et al., 2004; Jiang et al., 2011). In this sense, the correct positioning of cultivars within the agricultural zoning for a given region is a decisive factor for high yields, as this strategy results in significant changes in the genotype x production environment relationship (Barros et al., 2010; Meotti et al., 2012; Peixoto et al., 2000; Zanon et al., 2018).

The significance of the $\mathrm{G} \times \mathrm{E}$ interaction is characterized as one of the biggest problems of breeding programs, as it limits the performance of some cultivars in specific environments. The procedures adopted to circumvent and minimize the magnitude of the interaction is the recommendation of cultivars with wide adaptability and high phenotypic stability (Barros et al., 2010). Therefore, studies on $\mathrm{G} \times \mathrm{E}$ interaction are of great importance, as they provide information about the behavior of each genotype in the face of environmental variations (Yokomizo \& Santos, 2018; Barros, 2015).

One way of evaluating this interaction is the study of adaptability and stability of cultivars, by which it is possible to identify which ones have a predictable behavior and which respond positively to improvements in the environment, under specific or broad conditions (Cruz et al., 2012).

Cultivars with high genetic potential and stable when grown in different environments fits best farmer's demands and have a lower probability of yield frustration, making its positioning easier for different environments (Lemos et al., 2011; Vasconcelos et al., 2015).

Among the methods used to evaluate this pattern of behavior of soybean cultivars are AMMI (Additive Main effect and Multiplicative Interaction) (Gauch, 1992), GGE Biplot (Yan et al., 2000) and Centroide (Rocha et al., 2005).

The biplot methods AMMI and GGE are efficient in the analysis of the adaptability and stability of cultivars, when evaluated in different places, years and / or sowing times, since they facilitate the interpretation of the interaction in more than one dimension (Meotti et al., 2012).

In addition, the AMMI and GGE analysis allows the graphic representation of genotypes and environments in a multivariate dispersion diagram (Biplot). These diagrams provide information on phenotypic stability and adaptability and allow for agronomic zoning and the choice of specific environments for the evaluation and selection of cultivars (Meotti et al., 
2012; Yokomizo et al., 2013).

The Centroide method identifies the genotype of maximum general adaptability, maximum specific adaptability, to favorable or unfavorable environments, and genotypes with minimum adaptability (Rocha, 2005).

These analyzes can help to identify genotypes with high yield potential, well adapted and stable, for the purpose of recommending cultivars, or group of cultivars, for multiple or specific environments (Cruz et al., 2012; Yokomizo \& Santos, 2018).

For the south of Brazil, the soybean cultivars of intermediate RMG are more adapted and stable than smaller and larger RMG cultivars. These latter are more exposed to environmental factors under different growing conditions, precisely because of their shorter and longer cycle.

The aim of the work was to evaluate the performance, adaptability and stability of soybean cultivars, from different maturation groups, sown at different periods and growing seasons, in southwest Paraná.

\section{Material and Methods}

\subsection{Description of the Experiment Site}

The Experiment was carried out in the southwest of Paraná, latitude 25\%41'52" S, longitude $53^{\circ} 03^{\prime} 94^{\prime \prime} \mathrm{W}$, and altitude of 509 meters above the sea level, at the Experimental Station of the Universidade Tecnológica Federal do Paraná, Campus Dois Vizinhos. The soil of the experiment site is classified as a typical red Dystroferric Latosol (Embrapa, 2006).

Climate is classified as Cfa - Subtropical humid mesothermal climate, with no defined dry season and a mean annual rainfall of 2,000 $\mathrm{mm}$. Annual average temperature is around 20 to $22^{\circ} \mathrm{C}$. Summer is hot and frosts are uncommon in winter (Iapar, 2009).

\subsection{Study Details}

The experiment was carried out in field condition, forming four distinct groups of soybean cultivars depending on their cycle (Relative Maturity Group).

The nine cultivars tested were sown in three different times and in three growing seasons, according to Table 1, respecting the agricultural zoning for the adaptation region.

Table 1. Soybean cultivars and its respective relative maturity group (RMG).

\begin{tabular}{|c|c|}
\hline Cultivars & RMG \\
\hline NS 4823 RR $^{\circledR}$ & 4.8 \\
\hline $95 \mathrm{Y}^{2} \mathrm{RR}^{\circledR}$ & 5.0 \\
\hline 95Y52 RR ${ }^{\circledR}$ & 5.2 \\
\hline NS 5445 IPRO $^{\circledR}$ & 5.4 \\
\hline NS 5959 IPRO $^{\circledR}$ & 5.9 \\
\hline NS 6909 IPRO $^{\circledR}$ & 6.0 \\
\hline BRS 284 & 6.3 \\
\hline LG 60163 IPRO $^{\circledR}$ & 6.3 \\
\hline M 6410 IPRO $^{\circledR}$ & 6.4 \\
\hline
\end{tabular}




\section{Macrothink

The sowing occurred near on September20 $0^{\text {th }}(\mathrm{SEP})$; October $30^{\text {th }}(\mathrm{OCT})$ and December $20^{\text {th }}$ (DEC), in the three growing seasons (1: 2016/17; 2: 2017/18 and 3: 2018/19), ranging from one day to more or less.

Soybean soil fertilization was performed using a phosphorous source know as simple superfosphate $\left(18 \%\right.$ of $\left.\mathrm{P}_{2} \mathrm{O}_{5}\right)$ at a rate of $418 \mathrm{~kg} \mathrm{ha}^{-1}$. Potassium was broadcast at the $\mathrm{V}_{3}$ soybean phenological stage using $130 \mathrm{~kg}$ of $\mathrm{KCl} \mathrm{ha}^{-1}\left(60 \%\right.$ of $\left.\mathrm{K}_{2} \mathrm{O}\right)$. The management of weeds, pests and diseases was based on monitoring, applying products recommended for the protection crop, when justified.

\subsection{Variables Analyzed}

At harvest, five plants were randomly collected per experimental plot and subsequently evaluated for the following yield components: plant height $(\mathrm{PH}, \mathrm{cm})$, first pod insertion height (FPI, cm), number of pods per plant (NPP), number of grains per plant (NGP) and number of grains per pod (NGPP).

Soybean cultivar samples from the three central rows, each with 2 meters long (sample area $2.7 \mathrm{~m}^{2}$ per point) per plot were manually harvested, threshed by a stationary combine harvester and cleaned.

Moisture content of the grains was evaluated using portable automatic equipment and thousand grain weight (TGW, g) and final yield ( $\left.\mathrm{kg} \mathrm{ha}^{-1}\right)$ were adjusted to a moisture content of $12 \%$. Additionally, the TGW was assessed by manual counting and weighing eight samples of 100 grains.

\subsection{Statistical Analysis}

The residues were subjected to the normality and homogeneity test, after which the analysis of variance was performed. Analysis of the yield components and final grain yield, grouping of averages were used and tested by Scott Knott, at 5\% probability.

Analysis of adaptability and phenotypic stability of the genotypes, the mathematical models AMMI (Additive Main effect and Multiplicative Interaction) (Gauch, 1992), GGE Biplot (Yan et al., 2000) and Centroid (Rocha et al., 2005) were used.

The analyzes were performed with the aid of the statistical program Genes (Cruz, 2013).

\section{Results and Discussion}

The analysis of variance indicated an interaction between factors, cultivars and sowing periods (result in different production environments), for all variables analyzed (Table 2). 
Table 2. Analysis of the variance of nine soybean cultivars traits grown at nine different environments

\begin{tabular}{ccccccccc}
\hline & \multicolumn{8}{c}{ Medium square } \\
\cline { 3 - 9 } & & GH & FPI & NPP & NGP & NGPP & TGW & GY \\
\hline B/E & 18 & 15.79 & 4.35 & 130.13 & 876.76 & 0.01 & 45.08 & 75133.38 \\
$\mathrm{C}$ & 8 & $6524.16^{* *}$ & $550.20^{* *}$ & $2296.40^{* *}$ & $15179.74^{* *}$ & $0.10^{*}$ & $5647.14^{* *}$ & $915944.41 \mathrm{~ns}$ \\
$\mathrm{E}$ & 8 & $17149.97^{* *}$ & $473.86^{* *}$ & $2529.40^{* *}$ & $23932.64 * *$ & $1.11^{* *}$ & $17015.48^{* *}$ & $78934055.38^{* *}$ \\
$\mathrm{CxE}$ & 64 & $501.56^{* *}$ & $39.9 * *$ & $263.64 * *$ & $1178.61 * *$ & $0.04 * *$ & $598.68^{* *}$ & $1741716.62^{* *}$ \\
\hline $\mathrm{CV} \%$ & & 6.59 & 13.55 & 23.08 & 20.45 & 4.06 & 4.19 & 9.32 \\
\hline
\end{tabular}

$* *$, and $^{\mathrm{ns}}$, correspond, respectively, significant to $1 \%$ probability of error, significant to $5 \%$ probability of error and not significant. Variation factor (VF), block (B), cultivar (C), environment $(\mathrm{E})$, coefficient of variation $(\mathrm{CV})$, plant height $(\mathrm{PH}, \mathrm{cm})$, first pod insertion height (FPI, cm), number of pods per plant (NPP), number of grains per pod (NGP), number of grains per plant (NGPP), mass one thousand grains (TGW, g) and grain yield (GY, $\left.\mathrm{kg} \mathrm{ha}^{-1}\right)$.

Regarding to the plant height, comparing each cultivar within the production environments (sowing periods), it was noticed in general that soybean sowed in October showed taller plants than September or December sowing periods. Soybean cultivars sowed in September allowed better plant development resulting in taller soybean plants than December, for all three the crop years (Table 3).

Table 3. Results of the cluster analysis of means (Scott-Knott) for the interaction between cultivars $\mathrm{x}$ different environments

\begin{tabular}{|c|c|c|c|c|c|c|c|c|c|}
\hline \multirow{2}{*}{$\mathrm{C} / \mathrm{E}$} & \multicolumn{9}{|c|}{ Plant Height $(\mathrm{PH}, \mathrm{cm})$} \\
\hline & SEP1* & OCT1 & DEC1 & SEP2 & OCT2 & DEC2 & SEP3 & OCT3 & DEC3 \\
\hline 4823 & $55.8 \mathrm{eC}$ & $88.0 \mathrm{dA}$ & $69.7 \mathrm{bB}$ & $70.4 \mathrm{Fb}$ & $94.0 \mathrm{dA}$ & $25.8 \mathrm{dE}$ & $55.7 \mathrm{dC}$ & $60.7 \mathrm{dC}$ & $42.5 \mathrm{cD}$ \\
\hline $95 Y 72$ & $64.8 \mathrm{dC}$ & $91.7 \mathrm{dA}$ & $37.5 \mathrm{dE}$ & $45.1 \mathrm{gE}$ & $97.3 \mathrm{cA}$ & $25.3 \mathrm{dF}$ & $52.8 \mathrm{dD}$ & $83.3 \mathrm{bB}$ & $59.8 \mathrm{bC}$ \\
\hline $95 Y 52$ & $66.3 \mathrm{~dB}$ & $90.3 \mathrm{dA}$ & $36.3 \mathrm{dD}$ & 71.9fB & $87.1 \mathrm{dA}$ & $30.1 \mathrm{dD}$ & $45.6 \mathrm{eC}$ & $71.0 \mathrm{cB}$ & $43.1 \mathrm{cC}$ \\
\hline 5445 & $87.7 \mathrm{cB}$ & $102.0 \mathrm{cA}$ & $80.1 \mathrm{aC}$ & $94.8 \mathrm{Ea}$ & $99.5 \mathrm{cA}$ & $29.9 \mathrm{dF}$ & $66.9 \mathrm{cD}$ & $73.1 \mathrm{cD}$ & $47.3 \mathrm{cE}$ \\
\hline 5959 & $103.7 \mathrm{bB}$ & $109.0 \mathrm{cB}$ & $65.5 \mathrm{bD}$ & $129.5 \mathrm{Ba}$ & $104.3 \mathrm{cB}$ & $54.8 \mathrm{bE}$ & $85.9 \mathrm{bC}$ & $91.4 \mathrm{bC}$ & $35.3 \mathrm{dF}$ \\
\hline 6909 & $89.9 \mathrm{cB}$ & $103.5 \mathrm{cA}$ & $48.6 \mathrm{cD}$ & $110.1 \mathrm{Da}$ & $97.2 \mathrm{cB}$ & $41.3 \mathrm{cD}$ & $71.9 \mathrm{cC}$ & $73.5 \mathrm{cC}$ & $32.1 \mathrm{dE}$ \\
\hline 284 & $120.1 \mathrm{aB}$ & $133.3 \mathrm{aA}$ & $78.0 \mathrm{aD}$ & $122.0 \mathrm{Cb}$ & $132.7 \mathrm{aA}$ & 73.7aD & $72.1 \mathrm{cD}$ & $96.5 \mathrm{aC}$ & 73.0aD \\
\hline 60163 & $117.7 \mathrm{aA}$ & $124.5 \mathrm{bA}$ & $57.0 \mathrm{cC}$ & $125.8 \mathrm{bA}$ & $121.7 \mathrm{bA}$ & $46.8 \mathrm{cD}$ & $93.2 \mathrm{aB}$ & $99.2 \mathrm{aB}$ & $42.4 \mathrm{cD}$ \\
\hline \multirow[t]{2}{*}{6410} & $124.7 \mathrm{aB}$ & $135.5 \mathrm{aA}$ & $52.7 \mathrm{cF}$ & 140.3Aa & $121.5 \mathrm{bB}$ & $68.0 \mathrm{aE}$ & $80.0 \mathrm{bD}$ & $100.7 \mathrm{aC}$ & $45.5 \mathrm{cF}$ \\
\hline & \multicolumn{9}{|c|}{ First Pod Insertion (FPI, cm) } \\
\hline 4823 & $6.8 \mathrm{eC}$ & $10.9 \mathrm{eB}$ & $8.8 \mathrm{~dB}$ & $6.8 \mathrm{dC}$ & $14.9 \mathrm{cA}$ & $5.7 \mathrm{cC}$ & $9.7 \mathrm{~dB}$ & $15.2 \mathrm{dA}$ & $8.7 \mathrm{bB}$ \\
\hline $95 \mathrm{Y} 72$ & $7.2 \mathrm{eC}$ & $11.1 \mathrm{eB}$ & $12.0 \mathrm{~dB}$ & $7.7 \mathrm{dC}$ & $16.0 \mathrm{cA}$ & $8.2 \mathrm{cC}$ & $10.0 \mathrm{~dB}$ & $15.2 \mathrm{dA}$ & $10.8 \mathrm{aB}$ \\
\hline $95 Y 52$ & $10.7 \mathrm{dC}$ & $12.6 \mathrm{eB}$ & $10.8 \mathrm{dC}$ & $10.7 \mathrm{cC}$ & $18.9 \mathrm{cA}$ & $8.8 \mathrm{cC}$ & $9.9 \mathrm{dC}$ & $13.7 \mathrm{~dB}$ & $7.3 \mathrm{bC}$ \\
\hline 5445 & $18.9 \mathrm{bB}$ & $17.8 \mathrm{~dB}$ & $14.7 \mathrm{cC}$ & $13.5 \mathrm{cC}$ & $30.5 \mathrm{aA}$ & $10.8 \mathrm{cC}$ & $11.4 \mathrm{dC}$ & $17.7 \mathrm{cB}$ & $11.3 \mathrm{aC}$ \\
\hline 5959 & $23.6 \mathrm{aB}$ & $21.4 \mathrm{cB}$ & $22.9 \mathrm{aB}$ & $19.8 \mathrm{bC}$ & $32.8 \mathrm{aA}$ & $19.1 \mathrm{aC}$ & $15.6 \mathrm{bC}$ & $17.7 \mathrm{cC}$ & $7.2 \mathrm{bD}$ \\
\hline 6909 & $17.5 \mathrm{bB}$ & $21.1 \mathrm{cA}$ & $11.7 \mathrm{dC}$ & $12.0 \mathrm{cC}$ & $23.6 \mathrm{bA}$ & $9.7 \mathrm{cC}$ & $14.3 \mathrm{cC}$ & $19.9 \mathrm{cB}$ & $5.9 \mathrm{bD}$ \\
\hline 284 & $14.7 \mathrm{cA}$ & $9.5 \mathrm{eB}$ & $17.6 \mathrm{bA}$ & $19.4 \mathrm{bA}$ & $17.3 \mathrm{cA}$ & $14.8 \mathrm{bA}$ & $17.7 \mathrm{bA}$ & $16.3 \mathrm{dA}$ & $11.7 \mathrm{aB}$ \\
\hline 60163 & $18.7 \mathrm{bB}$ & $27.0 \mathrm{bA}$ & $14.9 \mathrm{cC}$ & $19.0 \mathrm{bB}$ & $25.8 \mathrm{bA}$ & $13.3 \mathrm{bC}$ & $20.2 \mathrm{aB}$ & $24.3 \mathrm{bA}$ & $7.9 \mathrm{bD}$ \\
\hline \multirow[t]{2}{*}{6410} & $22.8 \mathrm{aC}$ & $31.9 \mathrm{aA}$ & $13.8 \mathrm{cE}$ & $26.7 \mathrm{aB}$ & $31.7 \mathrm{aA}$ & $17.7 \mathrm{aD}$ & $22.3 \mathrm{aC}$ & $31.5 \mathrm{aA}$ & $10.5 \mathrm{aE}$ \\
\hline & \multicolumn{9}{|c|}{ Number of Pods per Plant (NPP) } \\
\hline 4823 & $33.6 \mathrm{bB}$ & $44.9 \mathrm{bA}$ & $40.4 \mathrm{bA}$ & $48.7 \mathrm{bA}$ & $44.4 \mathrm{bA}$ & $43.2 \mathrm{cA}$ & $33.6 \mathrm{aB}$ & $24.0 \mathrm{bB}$ & $23.4 \mathrm{bB}$ \\
\hline $95 Y 72$ & $45.0 \mathrm{bA}$ & $55.7 \mathrm{bA}$ & $42.5 \mathrm{bA}$ & $50.7 \mathrm{bA}$ & $42.9 \mathrm{bA}$ & $29.1 \mathrm{cB}$ & $35.7 \mathrm{aB}$ & $33.2 \mathrm{bB}$ & $26.9 \mathrm{bB}$ \\
\hline 95Y52 & $43.7 \mathrm{bB}$ & $49.2 \mathrm{bB}$ & $39.9 \mathrm{bB}$ & $43.6 \mathrm{bB}$ & $62.9 \mathrm{aA}$ & $32.1 \mathrm{cB}$ & $39.4 \mathrm{aB}$ & $39.4 \mathrm{bB}$ & $39.2 \mathrm{aB}$ \\
\hline 5445 & $37.1 \mathrm{bB}$ & $49.4 \mathrm{bA}$ & $36.3 \mathrm{bB}$ & $53.0 \mathrm{bA}$ & $46.6 \mathrm{bA}$ & $32.6 \mathrm{cB}$ & $42.3 \mathrm{aA}$ & $34.9 \mathrm{bB}$ & $22.7 \mathrm{bB}$ \\
\hline
\end{tabular}




\section{Il Macrothink}

Journal of Agricultural Studies

ISSN 2166-0379

2020, Vol. 8, No. 4

\begin{tabular}{cccccccccc}
\hline 5959 & $36.7 \mathrm{bC}$ & $59.8 \mathrm{bB}$ & $75.3 \mathrm{aA}$ & $80.7 \mathrm{aA}$ & $60.1 \mathrm{aB}$ & $63.6 \mathrm{aB}$ & $39.5 \mathrm{aC}$ & $42.1 \mathrm{bC}$ & $31.7 \mathrm{bC}$ \\
6909 & $44.7 \mathrm{bC}$ & $53.7 \mathrm{bB}$ & $62.3 \mathrm{aB}$ & $77.9 \mathrm{aA}$ & $59.1 \mathrm{aB}$ & $52.2 \mathrm{bB}$ & $34.1 \mathrm{aC}$ & $41.9 \mathrm{bC}$ & $34.3 \mathrm{bC}$ \\
284 & $62.0 \mathrm{aB}$ & $76.4 \mathrm{aA}$ & $67.9 \mathrm{aA}$ & $86.4 \mathrm{aA}$ & $70.6 \mathrm{aA}$ & $72.6 \mathrm{aA}$ & $48.0 \mathrm{aB}$ & $50.7 \mathrm{aB}$ & $55.9 \mathrm{aB}$ \\
60163 & $40.2 \mathrm{bB}$ & $44.3 \mathrm{bB}$ & $57.9 \mathrm{aB}$ & $88.6 \mathrm{aA}$ & $57.7 \mathrm{aB}$ & $51.0 \mathrm{bB}$ & $50.2 \mathrm{aB}$ & $41.9 \mathrm{bB}$ & $53.3 \mathrm{aB}$ \\
6410 & $41.5 \mathrm{bB}$ & $57.2 \mathrm{bA}$ & $37.7 \mathrm{bB}$ & $72.5 \mathrm{aA}$ & $69.3 \mathrm{aA}$ & $47.3 \mathrm{bB}$ & $42.7 \mathrm{aB}$ & $58.1 \mathrm{aA}$ & $44.3 \mathrm{aB}$ \\
\hline \multicolumn{7}{c}{ Number of Grain per Plant (NGP) } & & & \\
\cline { 2 - 10 } 4823 & $71.9 \mathrm{bB}$ & $106.7 \mathrm{bA}$ & $80.2 \mathrm{bB}$ & $119.5 \mathrm{bA}$ & $110.8 \mathrm{bA}$ & $91.6 \mathrm{Ba}$ & $72.9 \mathrm{aB}$ & $57.8 \mathrm{aB}$ & $43.5 \mathrm{bB}$ \\
$95 \mathrm{Y} 72$ & $93.5 \mathrm{bB}$ & $125.1 \mathrm{bA}$ & $85.8 \mathrm{bB}$ & $125.6 \mathrm{bA}$ & $114.7 \mathrm{bA}$ & $58.6 \mathrm{Bb}$ & $81.6 \mathrm{aB}$ & $89.9 \mathrm{aB}$ & $58.1 \mathrm{bB}$ \\
$95 \mathrm{Y} 52$ & $94.3 \mathrm{bB}$ & $113.1 \mathrm{bB}$ & $81.1 \mathrm{bB}$ & $108.1 \mathrm{bB}$ & $151.9 \mathrm{aA}$ & $65.5 \mathrm{bB}$ & $91.2 \mathrm{aB}$ & $99.4 \mathrm{aB}$ & $77.5 \mathrm{bB}$ \\
5445 & $89.3 \mathrm{bB}$ & $121.1 \mathrm{bA}$ & $74.5 \mathrm{bB}$ & $137.2 \mathrm{bA}$ & $124.0 \mathrm{bA}$ & $70.0 \mathrm{bB}$ & $99.5 \mathrm{aB}$ & $88.4 \mathrm{aB}$ & $48.7 \mathrm{bB}$ \\
5959 & $100.6 \mathrm{bC}$ & $146.7 \mathrm{bB}$ & $149.6 \mathrm{aB}$ & $204.7 \mathrm{aA}$ & $155.1 \mathrm{aB}$ & $126.6 \mathrm{aC}$ & $99.3 \mathrm{aC}$ & $108.1 \mathrm{aC}$ & $65.3 \mathrm{bD}$ \\
6909 & $111.0 \mathrm{bB}$ & $130.1 \mathrm{bB}$ & $140.9 \mathrm{aB}$ & $221.0 \mathrm{aA}$ & $148.1 \mathrm{aB}$ & $118.3 \mathrm{aB}$ & $82.9 \mathrm{aC}$ & $106.0 \mathrm{aB}$ & $64.5 \mathrm{bC}$ \\
284 & $182.2 \mathrm{aB}$ & $191.0 \mathrm{aB}$ & $135.6 \mathrm{aC}$ & $231.3 \mathrm{aA}$ & $184.4 \mathrm{aB}$ & $154.4 \mathrm{aC}$ & $110.5 \mathrm{aC}$ & $112.1 \mathrm{aC}$ & $111.2 \mathrm{aC}$ \\
60163 & $99.0 \mathrm{bB}$ & $107.3 \mathrm{bB}$ & $135.9 \mathrm{aB}$ & $227.6 \mathrm{aA}$ & $140.6 \mathrm{aB}$ & $119.9 \mathrm{aB}$ & $120.3 \mathrm{aB}$ & $102.3 \mathrm{aB}$ & $105.8 \mathrm{aB}$ \\
6410 & $107.5 \mathrm{bC}$ & $139.3 \mathrm{bB}$ & $78.3 \mathrm{bC}$ & $186.9 \mathrm{aA}$ & $166.1 \mathrm{aA}$ & $101.1 \mathrm{aC}$ & $109.7 \mathrm{aC}$ & $140 \mathrm{aB}$ & $95.6 \mathrm{aC}$ \\
\hline
\end{tabular}

Means in the same row followed by different capital letters and in the column followed by lowercase letters differ by the Scott-Knott test at 5\%. * Sep, Oct, Dec: sowing months; 1, 2 and 3: crop years 2016/2017, 2017/2018, 2018/2019, respectively; C: cultivar; E: environment.

At the third crop year (2018/19) soybean plants showed lower height compared to the two prior year, possible explained by two prolonged periods of water deficit, in November 2018 and in January 2019 (Figure 1), being the second more damaging, as it was longer than the first, significantly impacting the growth (plant height), especially in plants from December sowing (DEC3), which were in the vegetative phase. 

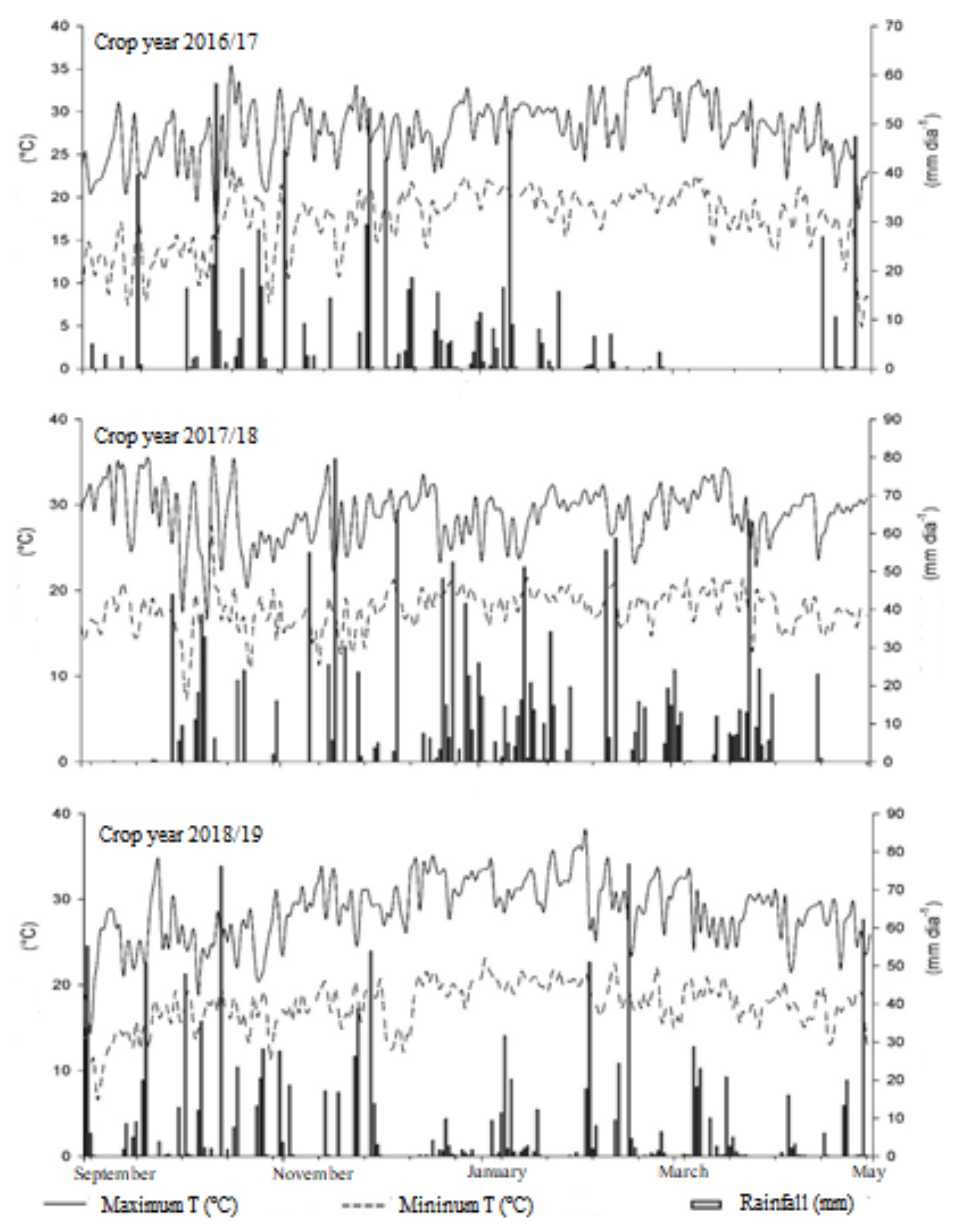

Figure 1. Maximum and minimum air temperature $\left({ }^{\circ} \mathrm{C}\right)$ and rainfall $\left(\mathrm{mm} \mathrm{day}^{-1}\right)$ along the experiment periods at the 2016/2017, 2017/2018 and 2018/2019 crop years. Dois Vizinhos -

PR. (Inmet, 2019)

Soybean plant development behavior may be explained by both temperature and photoperiod effects. Lower or milder temperatures at September, with averages below $10{ }^{\circ} \mathrm{C}$ (Figure 1) may have affected soybean growth. Thus, daylight length increases from July to December and than decrease from December to July. In this away and according to Sediyama et al. (2015), short daylight at September or at latter sowing periods (December) may stimulate earlier soybean flowering, resulting in shorter plants with less number of reproductive nodes, number of pods per plant and, consequently, lower grain yield.

According to Yokomizo \& Santos (2018), the height of the soybean plant, at the point of harvest, must be at least $0.50 \mathrm{~m}$ to allow an adequate mechanized harvest, with less losses; with an upper limit of $0.76 \mathrm{~m}$. For Silva et al. (2010), the ideal height of the soybean plant is $0.65 \mathrm{~m}$. In the present study, at the DEC2 and DEC3 periods (December sowing and its environments), many of the genotypes showed main stem length lower than $0.50 \mathrm{~m}$, which can be an aggravating factor in addition to adverse environmental conditions, resulting in even lower grain yield.

When analyzing the plant growth, among cultivars, for each environment, it was found that 
plant grow taller as RMG increases with a tendency to decrease as the cycle of cultivar is reduced. This behavior was even more striking in the December sowing. Similar results were reported by Pires et al. (2012), at Tocantins (Brazil state), allowing the association sowing period with its cycle and the final plant size.

Similar to that observed for the PH, the FPI in the main stem was greater in environments with sowing at October, and lower at December environments. When the cultivars for each environment were compared, those with a longer cycle (>RMG) had a higher FPI compared to those with a shorter cycle (Table 3).

According to Almeida et al. (2011), FPI less than $0.10 \mathrm{~m}$ may result in losses at harvest, since the combine platform is not able to properly cut and collect the pods inserted near to the soil. When observing Table 3, the earliest cultivars, in practically all environments, presented lower FPI than that indicated by the researcher as ideal.

Moreover, the NPP is one of the yield components that most varies in relation to the environment conditions. NPP from most of the cultivars was higher in the SEP2 environment, followed by the OCT2 and OCT1 environments (Table 3).

However, the variation of this yield component was smaller between environments, for each cultivar, compared to PH and FPI, having been less impacted by the environmental conditions. Cultivars NS 5959 and NS 6909 showed the lowest values in the third growing season year, regardless of the sowing period, indicating that these cultivars are more susceptible to water deficit when it comes to fixing pods in the plant.

Although there is similarity for NPP between cultivars, for each specific environment, there was a predominance of a greater number of pods in the larger and intermediate RMG cultivars, compared to the smaller RMG cultivars. In this sense, cultivar BRS 284 stood out and presented superior results in all analyzed environments (Table 3).

Similar results were observed by Cruz et al. (2010), in a study evaluating the performance of soybean cultivars according to the sowing date in Bahia, Brazil. The authors reported lower variation in NPP between cultivars than between seasons in which the late seasons conditioned a smaller number of pods per plant corroborating with Peixoto et al. (2000).

The NGP showed a similar trend to that observed for the NPP. However, it suffered greater variation, especially in the third crop year, in which the number of grains was lower for most of the cultivars, compared to the other production environments. Possibly due to the prolonged water deficit that occurred during soybean ontogeny, with greater sensitivity of BRS 284, NS 6909 and NS 5959. Although such cultivars stand out positively in NGP compared to the first cultivars, they were the most affected by the water deficit when analyzing their individual behavior among the other environments.

In general, the NGPP, within environments, for each cultivar was higher at SEP2 (sowing in September, $2^{\text {nd }}$ crop year), followed by OCT2 and OCT3 (sowing in October, $2^{\text {nd }}$ and $3^{\text {rd }}$ crop years). The lowest values of NGP were noticed at DEC1, DEC2 and DEC3 environments, all of them regarding to December sowing, indicating that factors such as shorter photoperiod, 
more persistent water deficit and higher temperatures (Figure 1) are an undesirable combination for soybean, regardless of the RMG of the cultivar (Table 4).

Table 4. Number of grain per pods (NGPP), thousand grain weight (TGW) and grain yield (GY) of nine soybean cultivars grown at nine different environment

\begin{tabular}{|c|c|c|c|c|c|c|c|c|c|}
\hline & \multicolumn{9}{|c|}{ Number of grain per pods (NGPP) } \\
\hline Cult & SEP1* & OCT1 & DEC1 & SEP2 & OCT2 & DEC2 & SEP3 & OCT3 & DEC3 \\
\hline 4823 & $2.15 \mathrm{Bb}$ & $2.37 \mathrm{aA}$ & $1.98 \mathrm{bC}$ & $2.47 \mathrm{Ba}$ & $2.5 \mathrm{Ba}$ & $2.13 \mathrm{bB}$ & $2.18 \mathrm{bB}$ & $2.43 \mathrm{bA}$ & $.85 b C$ \\
\hline $95 \mathrm{Y} 72$ & $2.06 \mathrm{Bd}$ & $2.24 \mathrm{bC}$ & $2.02 \mathrm{bD}$ & $2.47 \mathrm{Bb}$ & $2.67 \mathrm{aA}$ & $1.99 \mathrm{cD}$ & $2.29 b C$ & $2.71 \mathrm{aA}$ & $2.16 \mathrm{aC}$ \\
\hline $95 Y 52$ & $2.15 \mathrm{Bc}$ & $2.3 \mathrm{bB}$ & $2.04 \mathrm{bC}$ & $2.48 \mathrm{Ba}$ & $2.43 \mathrm{bA}$ & $2.01 \mathrm{cC}$ & $.32 \mathrm{bB}$ & $2.51 \mathrm{bA}$ & $.01 b C$ \\
\hline 5445 & $2.49 \mathrm{Ab}$ & $2.47 \mathrm{aB}$ & $2.04 \mathrm{bC}$ & $2.58 \mathrm{Ba}$ & $2.67 \mathrm{aA}$ & $2.07 \mathrm{cC}$ & $2.38 \mathrm{bB}$ & $2.53 \mathrm{bB}$ & $2.18 \mathrm{aC}$ \\
\hline 5959 & $56 \mathrm{Aa}$ & $2.46 \mathrm{aA}$ & $1.98 \mathrm{bB}$ & $2.54 \mathrm{bA}$ & $2.57 \mathrm{aA}$ & $1.99 \mathrm{cB}$ & $.55 \mathrm{aA}$ & $2.57 \mathrm{bA}$ & $.04 \mathrm{bB}$ \\
\hline 6909 & $2.49 \mathrm{Ab}$ & $2.42 \mathrm{aB}$ & $2.22 \mathrm{aC}$ & $2.92 \mathrm{aA}$ & $2.52 \mathrm{bB}$ & $2.21 \mathrm{bC}$ & $2.44 \mathrm{aB}$ & $2.54 \mathrm{bB}$ & $.93 \mathrm{bD}$ \\
\hline 284 & & $2.50 \mathrm{aA}$ & $97 \mathrm{bC}$ & $2.68 \mathrm{bA}$ & $2.64 \mathrm{aA}$ & $2.17 \mathrm{bB}$ & $2.28 \mathrm{bB}$ & $2.19 \mathrm{cB}$ & $.00 \mathrm{bC}$ \\
\hline 60163 & $2.47 \mathrm{Aa}$ & $2.41 \mathrm{aA}$ & $2.35 \mathrm{aA}$ & $2.54 \mathrm{bA}$ & $2.44 \mathrm{bA}$ & $2.33 \mathrm{aA}$ & $2.42 \mathrm{aA}$ & $2.44 \mathrm{bA}$ & $2.01 \mathrm{bB}$ \\
\hline \multirow[t]{2}{*}{6410} & & 2.43 & $\mathrm{oC}$ & $2.56 \mathrm{bA}$ & $2.31 \mathrm{bB}$ & $2.14 \mathrm{bC}$ & $2.57 \mathrm{aA}$ & $2.41 \mathrm{bA}$ & $2.17 \mathrm{aC}$ \\
\hline & \multicolumn{9}{|c|}{ Thousand grain weight $(\mathrm{TGW}, \mathrm{g})$} \\
\hline 4823 & D & $\mathrm{A}$ & $\mathrm{bC}$ & $184.7 \mathrm{bA}$ & $188.0 \mathrm{Ba}$ & $142.4 \mathrm{cD}$ & 7.5bD & $a c$ & $19.3 \mathrm{bE}$ \\
\hline $95 \mathrm{Y} 72$ & $\mathrm{Cb}$ & 208. & $\mathrm{bD}$ & $7.4 \mathrm{bB}$ & $.1 \mathrm{Bb}$ & $171.3 \mathrm{bC}$ & $5.0 \mathrm{bE}$ & $\mathrm{aD}$ & $37.3 \mathrm{aE}$ \\
\hline $95 Y 52$ & 1.9Aa & $19.1 \mathrm{aB}$ & $8.9 \mathrm{aD}$ & $199.2 \mathrm{aC}$ & 205.3Ac & 189.1aD & $160.1 \mathrm{aE}$ & $161.4 \mathrm{aE}$ & 133.0Af \\
\hline 5445 & $5.3 \mathrm{Ba}$ & $4.9 \mathrm{bA}$ & $164.4 \mathrm{bB}$ & $204.6 \mathrm{aA}$ & 196.6Aa & $163.7 \mathrm{bB}$ & $5.1 \mathrm{aB}$ & $39.7 \mathrm{cC}$ & 121.6bD \\
\hline 5959 & 7.2Ba & $3.6 \mathrm{cB}$ & $155.3 \mathrm{bD}$ & $180.5 \mathrm{bB}$ & $182.2 \mathrm{Bb}$ & $167.7 \mathrm{bC}$ & 151.2aD & $131.1 \mathrm{dE}$ & $117.0 \mathrm{bF}$ \\
\hline 6909 & $5.6 \mathrm{Ba}$ & $202.6 \mathrm{bA}$ & $158.4 \mathrm{bE}$ & $192.8 \mathrm{aB}$ & $179.4 \mathrm{Bc}$ & $169.7 \mathrm{bD}$ & $144.8 \mathrm{bF}$ & $124.0 \mathrm{dG}$ & $04.2 \mathrm{cH}$ \\
\hline 284 & 1.2Da & $0.1 \mathrm{~dB}$ & $138.5 \mathrm{cB}$ & $149.1 \mathrm{~dB}$ & $159.5 \mathrm{Ca}$ & $146.2 \mathrm{cB}$ & $115.9 \mathrm{cC}$ & $144.0 \mathrm{cB}$ & $117.6 \mathrm{bC}$ \\
\hline 60163 & $9.7 \mathrm{Ba}$ & $0.3 \mathrm{cB}$ & $180.8 \mathrm{aC}$ & $199.6 \mathrm{aA}$ & 206.1Aa & $192.4 \mathrm{aB}$ & $160.9 \mathrm{aD}$ & $127.0 \mathrm{dE}$ & $115.5 \mathrm{bF}$ \\
\hline \multirow[t]{2}{*}{6410} & $3.1 \mathrm{Ca}$ & $59.4 \mathrm{~dB}$ & $24.3 \mathrm{dD}$ & $160.9 \mathrm{cB}$ & $143 \mathrm{Dc}$ & $147.3 \mathrm{cC}$ & $139.7 \mathrm{bC}$ & $148.9 \mathrm{bC}$ & $105.0 \mathrm{cE}$ \\
\hline & \multicolumn{9}{|c|}{ Grain yield $\left(\mathrm{GY}, \mathrm{kg} \mathrm{ha}^{-1}\right)$} \\
\hline 4823 & $\mathrm{eC}$ & $\mathrm{AB}$ & $\mathrm{bD}$ & $6670 \mathrm{bA}$ & $705 \mathrm{Cb}$ & $1544 \mathrm{bF}$ & $\mathrm{aD}$ & $\mathrm{bE}$ & $980 \mathrm{cG}$ \\
\hline $95 \mathrm{Y} 72$ & $4746 \mathrm{C}$ & $4885 \mathrm{cC}$ & $3071 \mathrm{cD}$ & $5840 \mathrm{cA}$ & $5254 \mathrm{Ab}$ & $1564 \mathrm{bE}$ & $3231 \mathrm{bD}$ & $3249 \mathrm{aD}$ & $1499 \mathrm{E}$ \\
\hline $95 Y 52$ & $5336 \mathrm{cA}$ & $4881 \mathrm{cB}$ & $2993 \mathrm{cC}$ & $5741 \mathrm{cA}$ & $4946 \mathrm{Bb}$ & $2384 \mathrm{aD}$ & $2681 \mathrm{cC}$ & $2262 \mathrm{cD}$ & $1352 \mathrm{bE}$ \\
\hline 5445 & $4420 \mathrm{~dB}$ & $5200 \mathrm{cA}$ & $3067 \mathrm{cC}$ & $5487 \mathrm{cA}$ & $5363 \mathrm{Aa}$ & $1499 \mathrm{bE}$ & $3329 \mathrm{bC}$ & $2442 \mathrm{cD}$ & $1180 \mathrm{bE}$ \\
\hline 5959 & $5772 \mathrm{bB}$ & $6325 \mathrm{aA}$ & $3117 \mathrm{cD}$ & $5542 \mathrm{cB}$ & $5659 \mathrm{Ab}$ & $2498 \mathrm{aE}$ & $3903 \mathrm{aC}$ & $2108 \mathrm{cE}$ & $757 \mathrm{cF}$ \\
\hline 6909 & $5871 \mathrm{bB}$ & $6058 \mathrm{aB}$ & $2864 \mathrm{cE}$ & $7173 \mathrm{aA}$ & $5089 \mathrm{Bc}$ & $2313 \mathrm{aF}$ & $3663 \mathrm{aD}$ & $2069 \mathrm{cF}$ & $647 \mathrm{cG}$ \\
\hline 284 & $5712 \mathrm{bB}$ & $5677 \mathrm{bB}$ & $2119 \mathrm{dE}$ & $7289 \mathrm{aA}$ & $4902 \mathrm{Bc}$ & $2674 \mathrm{aD}$ & $3044 \mathrm{bD}$ & $2218 \mathrm{cE}$ & $2728 \mathrm{aD}$ \\
\hline 60163 & $5238 \mathrm{cB}$ & $4911 \mathrm{cB}$ & $3933 \mathrm{aC}$ & $6908 \mathrm{bA}$ & $4143 \mathrm{Dc}$ & $2716 \mathrm{aD}$ & $3958 \mathrm{aC}$ & $2181 \mathrm{cE}$ & $1105 \mathrm{bF}$ \\
\hline 6410 & $6259 \mathrm{aA}$ & $5649 \mathrm{bB}$ & $2191 \mathrm{dE}$ & $5760 \mathrm{cB}$ & $4356 \mathrm{Dc}$ & $2688 \mathrm{aD}$ & $3144 \mathrm{bD}$ & $2866 \mathrm{bD}$ & $1339 \mathrm{bF}$ \\
\hline
\end{tabular}

Means in the same row followed by different capital letters and in the column followed by lowercase letters differ by the Scott-Knott test at 5\%. * Sep, Oct, Dec: sowing months; 1, 2 and 3: crop years 2016/2017, 2017/2018, 2018/2019, respectively; C: cultivar; E: environment.

When comparing NGPP within each production environment, among cultivars, it appears that it is highly variable, although there is a greater number of grains per pod for the larger and intermediate RMG cultivars with a greater (Table 4).

All December sowing periods resulted in lower TGW. Also, at the $3^{\text {rd }}$ crop year, regardless of the sowing season, this variable was compromised due to water deficit (Table 4). The environments that most favored TGW were SEP1, followed by OCT1 and OCT2, and finally, SEP2, for most of the evaluated cultivars.

When analyzing the cultivars, in each environment, it is possible to verify that TGW is an 
intrinsic trait of the genotype, with emphasis on the cultivar 95Y52, followed by 60163 and 5445 , which presented greater mass in most production environments. The cultivars with the lowest TGW were BRS 284 and M6410 (Table 4).

These results corroborate with Cruz et al. (2010) and Dalchiavon \& Carvalho (2012), in which both genetic and environmental influence was found for soybean TGW, however, the importance of genetics in this character was evidenced, mainly in favorable conditions.

Final GY in relation to the different environments, for each cultivar, was generally higher in SEP2 (Sowing in September, $2^{\text {nd }}$ crop year) following the trend observed for the yield components (Table 4). Soybean is a very plasticity specie in a way that one yield component may be offset by other yield components aiming to maintain final yield potential. In these way, OCT1 (Sowing in October, $1^{\text {st }}$ crop year) and SEP1 (Sowing in September, $1^{\text {st }}$ crop year) environments were also favorable for higher yields and, in an intermediate way, the OCT2 environment (Sowing in October, $2^{\text {nd }}$ crop year).

This result is accordance with those reported by Albrecht et al. (2008). The authors evaluated the GY of three soybean cultivars in five sowing seasons (09/15;09/30;10/15;10/30 and 11/15), and concluded that the sowing dates of $09 / 30,15 / 10$ and $10 / 30$ conferred the highest productivity.

The environments DEC1, DEC2, SEP3, OCT3 and DEC3 were unfavorable for GY. In the three crop years, the worst conditions were verified in December sowing, corroborating with Marques et al. (2011), in a study carried out in Minas Gerais state, to evaluate the performance of soybean genotypes according to the sowing date. Only in the last crop year that the unfavorable results occurred in the three seasons, SEP3, OCT3 and DEC3, due to the prolonged water deficit that occurred; but even so, the DEC3 environment was the most harmful for soybean GY (Table 4).

According to Meotti et al. (2012) and Jiang et al. (2011) in late sowing (short photoperiod), soybeans bloom early, have reduced size and cycle and, consequently, lower GY potential which is in accordance with what was verified in the present study. Therefore, the cultivation of soybeans in late sowing periods should adopt medium cycle cultivars with high height (Peixoto et al., 2000).

When comparing the cultivars, for each specific environment, it was possible to verify a range of responses among the materials. However, those close to RMG 6.0, represented by NS 5959 and NS 6909, were the cultivars that stood out in the greatest number of environments, with four observations, on average per cultivar (sum of observations with higher productivity for both cultivars, divided by the number of cultivars in the group).

Cultivars near to RMG 6.3 (BRS 284, LG 60163 and M6410) had, on average per cultivar, 2.7 positive observations for GY. In sequence, representatives of RMG 5.0 (NS 4823 and P95Y72, the earliest), stood out, on average per cultivar, in 1.5 observations. The cultivars that least stood out individually for grain productivity, in comparison of these, for each environment, were the representatives of RMG 5.3 (P95Y52 and NS 5445), with 1 observation each. 


\section{Ml Macrothink}

Journal of Agricultural Studies

ISSN 2166-0379

2020, Vol. 8, No. 4

Regarding to the lowest GY, for each cultivar, representatives of RMG 5.0 had 3.5 observations; RMG 5.3, 3 observations; RMG 6.0, 2.5 observations; and, finally, those with the lowest number of negative results for cultivar were representatives of RMG 6.3, with 2.3 observations.

Thus, it was found that the cultivars representing RMG 6.0 were the ones that showed the highest productive balance in the average of the 81 observations made (nine environments $\mathrm{x}$ nine cultivars), being the RMG 5.3 the most volatile cultivars.

However, in very unfavorable environments, the cultivars most negatively impacted were NS 5959 and NS 6909 at the DEC3 (Table 4). Thus, the importance of knowing the individual response of soybean cultivars to specific environments is emphasized, in order to achieve a correct positioning of the cultivars, and sustainable productivity, even with variations in the production environment.

The cultivar that should be targeted for genetic improvement is the one that has a positive response to the improvement of the production environment, and low yield reduction in unfavorable environments, as reported by Freiria et al. (2018), with the BMX Potência RR, UEL 110, UEL 121 and UEL 123 genotypes.

The analyzes of adaptability and stability of cultivars in different environments, were carried out on GY, given the interest and main objective of the research. The results of the joint variance analysis indicated a significant interaction between the factors (Table 5), showing differentiated response of the genotypes according to the production environments, which suggests a more detailed analysis.

Table 5. Results of the AMMI analysis from the interaction among nine soybean cultivars grown in nine environments for the grain yield $\left(\mathrm{kg} \mathrm{ha}^{-1}\right)$ variable

\begin{tabular}{lcccc}
\hline Variation Source & DF & Medium square & F & P>F \\
\hline Cultivars (C) & 8 & 305314.804 & 0.909641 & 0.514316 \\
Environments (E) & 8 & 26311351.8 & 78.39081 & 0.000 \\
Interaction - C×E & 64 & 335643.309 & 2.678571 & 0.000 \\
\hline IPCA1 & 15 & 536182.068 & 4.279 & 0.000001 \\
IPCA2 & 13 & 406993.734 & 3.248 & 0.000195 \\
IPCA3 & 11 & 406705.222 & 3.2457 & 0.000459 \\
IPCA4 & 9 & 240676.05 & 1.9207 & 0.051565 \\
IPCA5 & 7 & 151059.935 & 1.2055 & 0.301897 \\
IPCA6 & 5 & 83161.314 & 0.6637 & 0.651461 \\
IPCA7 & 3 & 9549.38 & 0.0762 & 0.972762 \\
IPCA8 & 1 & 5806.035 & 0.0463 & 0.829875 \\
\hline Average error & 180 & 125306.835 & &
\end{tabular}

In the result of the AMMI analysis, the three main components were significant by the F test, with explanation of the variation of the SQG $x$ E $59.75 \%$ of the IPCA1. IPCA 2 explained $21.26 \%$ of the interaction, while IPCA 3 explained $21.17 \%$. In this analysis, the ideal that the first two main components explain $70 \%$ or more of the total accumulated and explained variation of all components (Alcântara Neto et al., 2018). In the present study, it was $81.01 \%$ 
for IPCA1 and IPCA2, in agreement with Silveira et al. (2018).

According to Gauch Jr. (2013), as the number of selected axes increases, the percentage of "noise" also increases, reducing the predictive power of the AMMI analysis, that is, the excessive inclusion of multiplicative terms can reduce the accuracy of the analysis. Therefore, in the present study, only the axes IPCA 1 and IPCA 2 were considered in the AMMI analysis.

The BRS 284, 6909 and 5959 cultivars presented above average yields, and the most stable cultivar was 95Y52, being able to be cultivated in all environments, indicating that the most productive cultivars were not, likewise, stable. The less productive cultivars, in addition to 95Y52, were 4823, $95 \mathrm{Y} 72$ and 5445 (Figure 2a), all of them are genotypes with a shorter cycle. In addition, cultivars 4823 and 6410 were the ones that most contributed to the $\mathrm{G} \times \mathrm{E}$ interaction, as they had the highest score range in the interaction axis, followed by 284 and $95 \mathrm{Y} 72$.
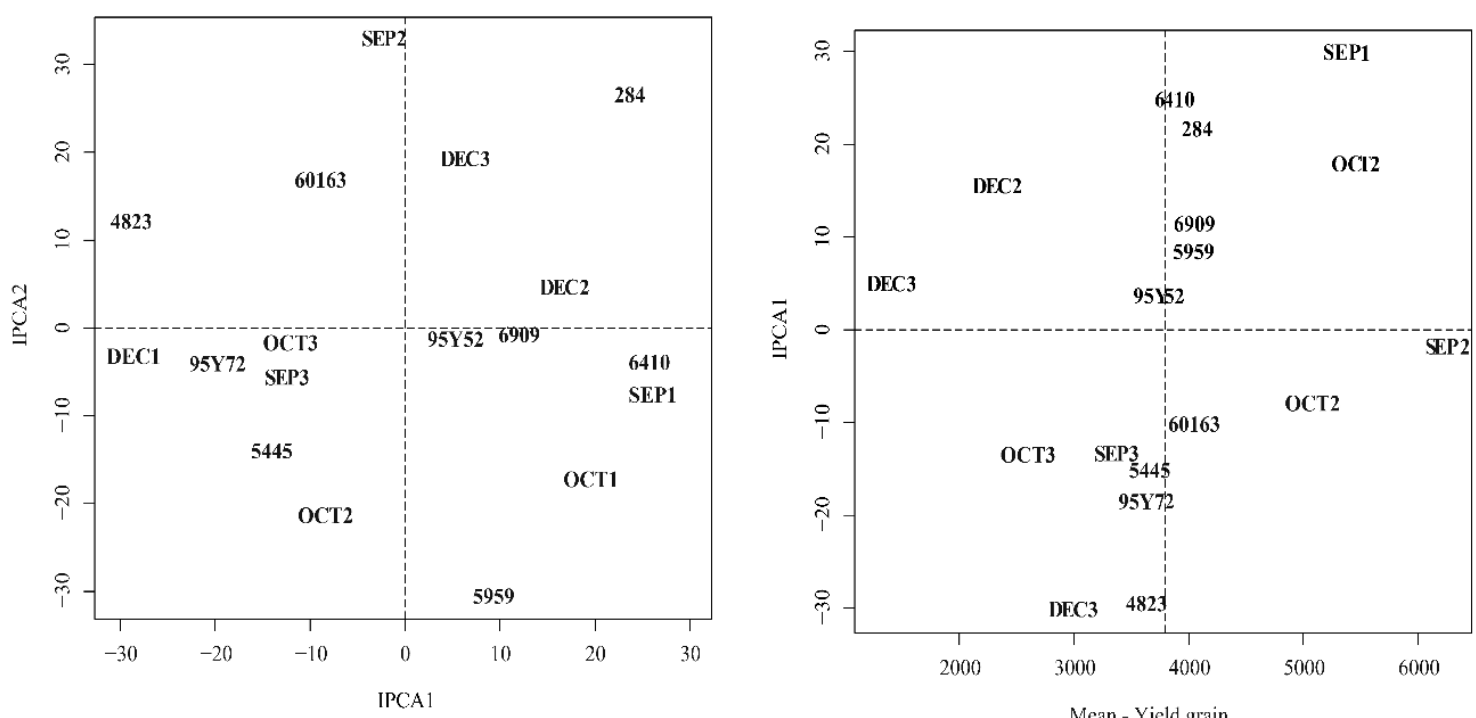

Figure 2. Analysis of the AMMI dispersion of the nine soybean cultivars in the nine cultivation environments for the grain yield variable $\left(\mathrm{kg} \mathrm{ha}^{-1}\right)$. SEP1: 2016/17 crop year season 1; OCT1: 2016/17 crop year - season 2; DEC1: 2016/17 crop year - season 3; SEP2: 2017/18 crop year - season 1; OCT2: 2017/18 crop year - season 2; DEC2: 2017/18 crop year - season 3; SEP3: 2018/19 crop year - season 1; OCT3: 2018/19 crop year - season 2; e DEC3: 2018/19 crop year - season 3

Silveira et al. $(2016 ; 2018)$, using the AMMI methodology, reported that the earliest cultivar, SYN 1049, was the most unstable one compared to the cultivars of higher RMG. This occurred in the present study for NS 4823, with a RMG of 4.8, indicating that very early genotypes require greater attention for their cultivation, both in terms of management, as well as the prevailing edaphoclimatic conditions.

The most favorable environments for soybean productivity were SEP2 (Sowing in September, $1^{\text {st }}$ crop year), followed by OCT1, DEC1 and OCT2. The most unfavorable environment was DEC3, (Sowing in December, $3^{\text {rd }}$ crop year).

The use of an AMMI 2 biplot (IPCA 1 vs. IPCA 2) (Figure 2) allows the correction of 
possible distortions in the analysis or interpretation produced using a single dimension (Yokomizo et al., 2013).

The adaptability of the genotypes in each cultivation site is interpreted from the score signs for genotypes and environments, and the genotypes and environments of the same sign $(+,+$ or -, -) interact positively. On the other hand, when there are opposite signs $(+,-$ or,-+$)$ they present negative interaction (Duarte \& Vencovsky, 1999), indicating in which environment the genotype should be cultivated preferentially.

The 95Y52 cultivar remained the most stable, corroborating with the AMMI1 biplot. It was also found that genetics related to higher productivity seems to be associated with specific adaptations. Example of cultivar 6410, with higher productive performance, and close to the SEP1 environment. Subsequently, BRS 284, however, of broader adaptation, with greater synergism to the DEC2 and DEC3 environments.

Similar to the AMMI1 biplot, but with greater amplitude, the cultivar 4823 proved to be one of the least productive. Regarding the contribution of the cultivar to the interaction, NS 5959 stood out in comparison to the others, followed by BRS 284 .

All environments, in general, contributed to the interaction $\mathrm{G} \times \mathrm{E}$, with emphasis on SEP1, DEC1 and SEP2. From the point of view of plant breeding, this situation increases the challenges for the recommendation of cultivars aiming at mega environments, conditioning the cultivar launch to more specific environments.

It was verified, by the GGE Biplot method, greater contribution of cultivars 5959 and 60163 with the interaction G x E, and environments SEP1 and SEP2 (sowing in September, $1^{\text {st }}$ and $2^{\text {nd }}$ crop years). As for environments with less collaboration for interaction, SEP3 and OCT3 stand out. Using this method, the 95Y52 cultivar was again more stable.

In the GGE method (Figure 3), smaller, greater and equal angles of 90 degrees indicate positive, negative and no association, respectively, between environments and cultivars.
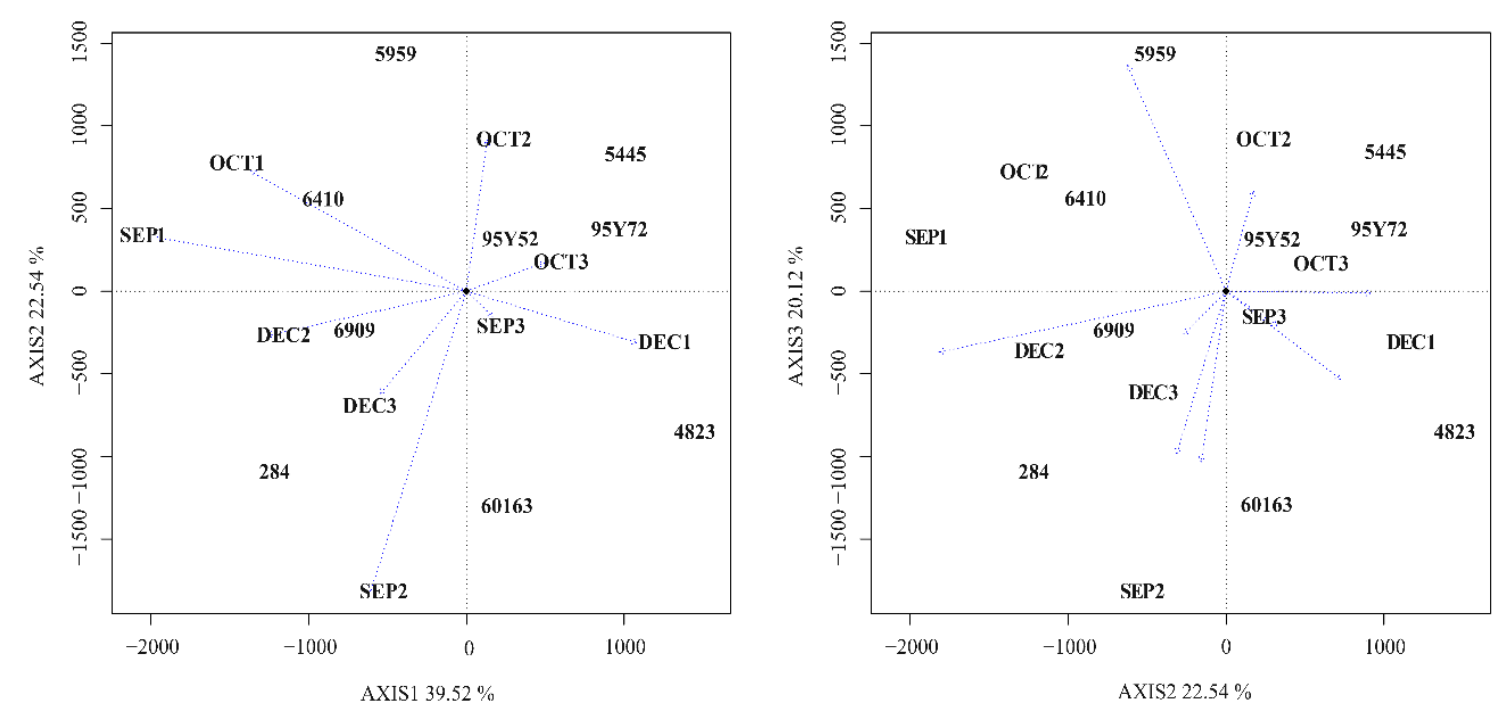
Figure 3. Analysis of the GGE Biplot dispersion of the nine soybean cultivars in the nine cultivation environments for the grain yield variable $\left(\mathrm{kg} \mathrm{ha}^{-1}\right)$. SEP1: 2016/17 crop year season 1; OCT1: 2016/17 crop year - season 2; DEC1: 2016/17 crop year - season 3; SEP2: 2017/18 crop year - season 1; OCT2: 2017/18 crop year - season 2; DEC2: 2017/18 crop year - season 3; SEP3: 2018/19 crop year - season 1; OCT3: 2018/19 crop year - season 2; e DEC3: 2018/19 crop year - season 3

The earliest cultivars (95Y72, 5445 and 95Y52) showed a positive association with the OCT2 and OCT3 environments; with greater interaction between the last two and OCT3; and 95 Y72 with OCT2. NS 4823 cultivar was strongly associated with SEP3. The best performance of earlier cultivars can be seen in October sowing, but also in late September. These results are partially in agreement with Meotti et al. (2012), who attributed the favorable performance of the soybean cultivars tested to the conditions of temperature, solar radiation and photoperiod prevalent in October sowing.

The BRS 284 cultivar was positively associated with DEC2, 6909 with DEC2. The 6410 had a positive interaction with the OCT1. In a biplot, specific adaptations can be explored that can allow the breeder to make better use of his study materials both in the selection and in the recommendation of cultivars (Polizel et al., 2013).

The results of the analysis of the main components for the centroid method indicated that the two main components explained $63 \%$ of the total variation, being a value considered adequate for estimating the interaction of factors (Table 6).

Table 6. Results of the analysis of main components to estimate adaptability via the centroid method, average yield $\left(\mathrm{kg} \mathrm{ha}^{-1}\right)$ and the classification of genotypes in one of the four groups characterized by the centroid and the probability associated with their classification of soybean genotypes

\begin{tabular}{rrrrrrrrrr}
\hline Root $^{1}$ & Root (\%) & \% Acum & Cultivar $^{2}$ & Average & Classif. & Prob(I) & Prob(II) & Prob(III) & Prob(IV) \\
\hline 2.93 & 32.56 & 32.56 & 95 Y52 & 3619.61 & IV & 0.202 & 0.241 & 0.240 & 0.317 \\
2.76 & 30.66 & 63.22 & 5445 & 3554.18 & IV & 0.186 & 0.220 & 0.246 & 0.348 \\
1.13 & 12.60 & 75.82 & $95 Y 72$ & 3704.34 & IV & 0.209 & 0.217 & 0.277 & 0.297 \\
0.99 & 11.01 & 86.83 & 4823 & 3587.06 & IV & 0.191 & 0.203 & 0.281 & 0.325 \\
0.69 & 7.63 & 94.46 & 6410 & 3805.83 & II & 0.240 & 0.285 & 0.221 & 0.255 \\
0.30 & 3.33 & 97.79 & 5959 & 3964.59 & II & 0.261 & 0.304 & 0.208 & 0.227 \\
0.17 & 1.90 & 99.69 & 284 & 4040.33 & I & 0.300 & 0.285 & 0.210 & 0.205 \\
0.02 & 0.26 & 99.95 & 60163 & 3899.24 & III & 0.254 & 0.222 & 0.284 & 0.241 \\
0.00 & 0.05 & 100.00 & 6909 & 3971.77 & II & 0.240 & 0.402 & 0.163 & 0.195 \\
\hline
\end{tabular}

1 Analysis of main components; ${ }^{2}$ Analysis of adaptability via centroid for nine soybean cultivars. Overall average 3794.1. Ideotype I: High general adaptability. Ideotype II: Specific adaptability to favorable environments; Ideotype III: Specific adaptability to unfavorable environments and Ideotype IV: Little adapted.

The analysis of the graph of the main components, for the productive adaptability of the genotypes, by the centroid method, indicated that only the cultivar BRS 284 showed high general adaptability, since it was closer to ideotype I (Figure 4, Table 6), obtaining the highest 
average productivity.

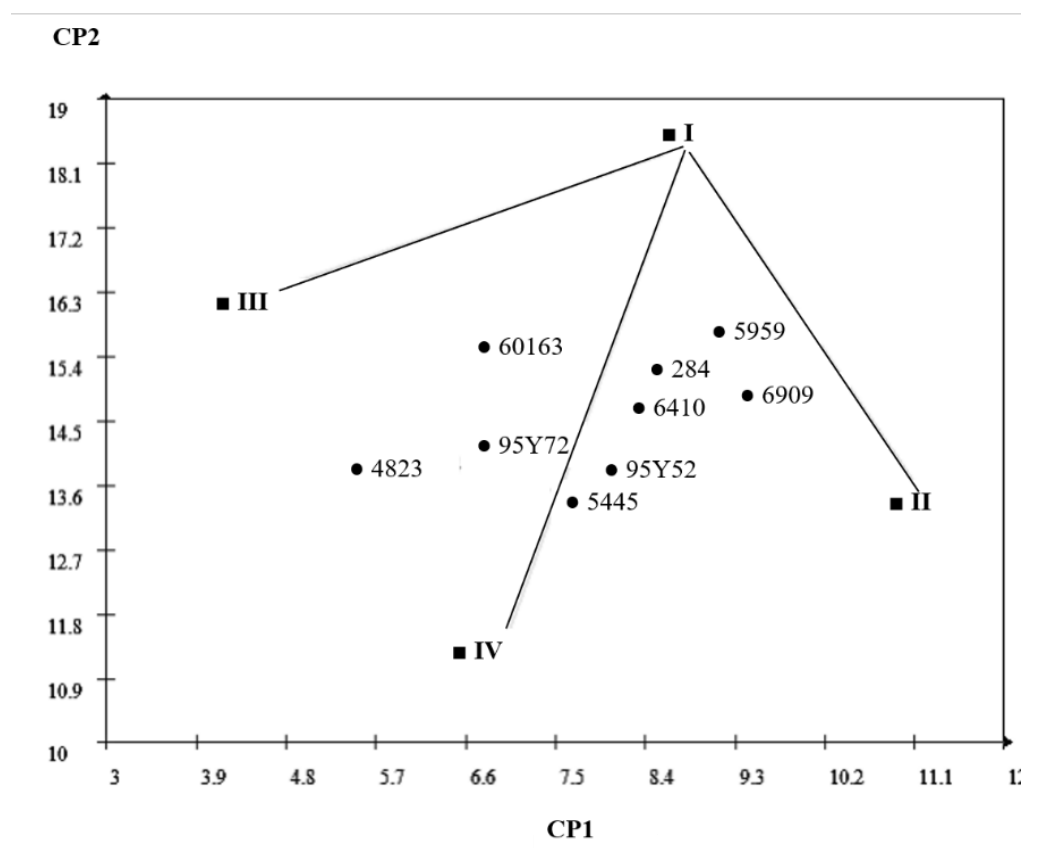

Figure 4. Graphical dispersion of the scores in relation to the first two main components obtained from the analysis of grain yield of nine soybean cultivars evaluated in nine environments. The four points numbered with Roman numerals represent the centroid

The 6410, 5959 and 6909 cultivars showed specific adaptation to favorable environments, since they were closer to ideotype II. The 60163 cultivar, on the other hand, showed specific adaptability to unfavorable environments, indicating that it is a promising genotype for more stressful conditions for soybean crops. In this method, the genotype of maximum specific adaptation is not the one that performs well in groups of favorable or unfavorable environments, but the genotype that shows maximum values for a given group of environments (favorable and unfavorable) and minimum for the other group (Pelúzio et al., 2010).

Shorter cycle cultivars (95Y52, 5445, 95 Y72 and 4823) showed the lowest adaptation. These cultivar patterns are more susceptible to adverse conditions of environment and management, due to their reduced cycle, smaller size and, consequently, less phenotypic plasticity, in general, compared to cultivars with a longer cycle, requiring more caution in their recommendation.

Unfavorable environments are characterized by areas of cultivation whose technological index is low or regions with adverse edaphic and climatic conditions. Favorable environments are associated with regions with climatic and edaphic conditions appropriate to the suitability of the crop, or cultivation areas where high production technology is employed (Pelúzio et al., 2010).

As in our study, Vasconcelos et al. (2015) stratified soybean genotypes according to their adaptation in different environments by the centroid method, obtaining reliable results through this tool. 


\section{Macrothink}

\section{Conclusion}

The NS 5909 IPRO® and NS 6909 IPRO® cultivars, both close to GMR 6.0, presented superior average performance in most of the evaluated production environments. The earliest cultivars, with GMR less than 5.4, were the ones that produced less, in general, in different environments.

Evaluated soybean cultivars specific adaptations stood out in relation to general adaptation, showing the importance of genotype environment interaction and the use of the right cultivar according to the environment.

The adaptability of the genotypes was not accompanied by high stability, which contributes to the reduction of the average productivity of the cultivars when exposed to different environments.

\section{Acknowledgements}

To CNPq, CAPES and Fundação Araucária for granting a scholarship and other financial aid for the execution of the research.

The authors inform that there is no conflict of interest in conducting the research, nor regarding the publication of the manuscript.

\section{References}

Albrecht, L. P., Braccini, A. de L. e, Scapim, C. A., Aguiar, C. G. de, Ávila, M. R., \& Stülp, M. (2008). Qualidade fisiológica e sanitária das sementes sob semeadura antecipada da soja. Scientia Agraria, 9(4), 445-454. https://doi.org/10.5380/rsa.v9i4.12476

Alcântara Neto, F. de, Tavares, S. de O., Leite, W. de S., Silva, J. A. L. da., Matos Filho, C. H. A. \& Gravina, G. de A. (2018). Grain yield, adaptability and stability of soybean genotypes in different Cerrado environments of Piauí, Brazil. Comunicata Scientiae, 9(2), 226-234. https://doi.org/10.14295/cs.v9i2.2674

Almeida, R. D., Pelúzio, J. M., \& Afférri, F. S. (2011). Divergência genética entre cultivares de soja, sob condições de várzea irrigada, no sul do Estado Tocantins. Revista Ciência Agronômica, 42(1), 108-115. https://doi.org/10.1590/S1806-66902011000100014

Barros, H. B., Sediyama, T., Cruz, C. D., Teixeira, R. de C., \& Reis, M. S. (2010). Análise de adaptabilidade e estabilidade em soja (Glycine max L.) em Mato Grosso. Ambiência, 6(1), 75-88. https://revistas.unicentro.br/index.php/ambiencia/article/view/976/984.

Barros, H. B., Sediyama, T., Teixeira, R. de C., Fidelis, R. R., Cruz, C. D., \& Reis, M. S. (2015). Adaptabilidade e estabilidade de genótipos de soja avaliados no estado do Mato Grosso. Ceres, 57(3), 359-366. https://doi.org/10.1590/S0034-737X2010000300011 
Braccini, A. de L. e, Motta, I. de S., Scapim, C. A., Braccini, M. do C. L., Ávila, M. R., \& Meschede, D. K. (2004). Características agronômicas e rendimento de sementes de soja na semeadura realizada no período de safrinha. Bragantia, 63(1), 81-92. https://doi.org/10.1590/ S0006-87052004000100009

Carvalho, E. R., Rezende, P. M. de, Ogoshi, F. G. A., Botrel, E. P., Alcântara, H. P. de, \& Santos, J. P. (2010). Desempenho de cultivares de soja [Glycine max (1.) merrill] em cultivo de verão no sul de Minas Gerais. Ciência \& Agrotecnologia, 34(4), 892-899. https://doi.org/10.1590/ S1413-70542010000400014

Cruz, C. D., Regazzi, A. J., \& Carneiro, P. C. S. (2012). Modelos biométricos aplicados ao melhoramento genético. $3^{\mathrm{a}}$ ed. Viçosa, MG: UFV. 2012. 668p.

Cruz, C. M. (2013) Genes: a software package for analysis in experimental statistics and quantitative genetics. Acta Scientiarum. Agronomy, 35, 271-276. https://doi.org/10.4025/actasciagron.v35i3.21251

Cruz, T. V. da., Peixoto, C. P., Martins, M. C., \& Peixoto, M. de F. da S. P. (2010). Soybean yield components in different sowing periods in the western of state of Bahia. Bioscience Journal, 26(5), 709-716.

Dalchiavon, F. C., \& Carvalho, M. de P. e. (2012) Correlação linear e espacial dos componentes de produção e produtividade da soja. Semina: Ciências Agrárias, 33(2), 541-552. https://doi.org/10.5433/1679-0359.2012v33n2p541

Duarte, J. B., \& Vencovsky, R. (1999). Interação genótipos x ambientes: uma introdução à análise AMMI. Ribeirão Preto: Sociedade Brasileira de Genética. (60p.). Série Monografias, 9 .

Embrapa. Centro Nacional de Pesquisas de solo (2006). Sistema brasileiro de classificação de solos-2.ed.-Rio de Janeiro: Embrapa Solos. 306p.

Freiria, G. H., Gonçalves, L. S. A., Furlan, F. F., Fonseca Júnior, N. da S., Lima, W. F., \& Prete, C. E. C. (2018). Statistical methods to study adaptability and stability in breeding lines of food-type soybeans. Bragantia, 77(2), 253-264. https://doi.org/10.1590/1678-4499.2017076

Gauch Júnior, H. G. (2013). A simple protocol for AMMI analysis of yield trials. Crop Science, 53. 1860-1869. https://doi.org/10.2135/cropsci2013.04.0241

Gauch, H. G. (1992). Statistical analysis of regional yield trials: AMMI analysis of factorial designs, Amsterdam, Elsevier.

Iapar. (2009). Cartas climáticas do Estado do Paraná. Londrina: IAPAR.

Inmet - Instituto Nacional de Meteorologia (2018). Estações automáticas, Dois Vizinhos. 错 误!超链接引用无效。

Jiang, Y., Wu, C., Zhang, L., Hu, P., Hou, W., Zu, W., \& Han, T. (2011). Long-day effects on the terminal inflorescence development of a photoperiod-sensitive soybean [Glycine max (L.) Merr.] variety. Plant Science, 180(3), 504-510. https://doi.org/10.1016/j.plantsci.2010.11.006 
Lemos, L. B., Farinelli, R., Cavariani, C., \& Zapparoli, R. A. (2011). Desempenho agronômico e produtivo de cultivares de soja em diferentes safras. Científica, 39(1/2), 44-51. https://doi.org/10.15361/1984-5529.2011v39n1\%2F2p44+-+51

Marques, M. C., Hamawaki, O. T., Sediyama, T., Bueno, M. R., Reis, M. S., Cruz, C. D., \& Nogueira, A. P. O. (2011). Adaptabilidade e estabilidade de genótipos de soja em diferentes $\begin{array}{lllll}\text { épocas de } & \text { semeadura. } & \text { Bioscience } & \text { Journal, } & \text { 27(1), }\end{array}$ http://www.seer.ufu.br/index.php/biosciencejournal/article/view/7388/6842

Meotti, G. V., Benin, G., Silva, R. R., Beche, E., \& Munaro, L. B. (2012). Épocas de semeadura e desempenho agronômico de cultivares de soja. Pesquisa Agropecuária Brasileira, 47(1), 14-21. https://doi.org/10.1590/S0100-204X2012000100003

Peixoto, C. P., Câmara, G. M. de S., Martins, M. C., Marchiori, L. F. S., Guerzoni, R. A., \& Mattiazzi, P. (2000). Épocas de semeadura e densidade de plantas de soja: componentes da produção e rendimento de grãos. Scientia Agricola, 57(1), 47-61. https://doi.org/10.1590/S0103-90162000000100015

Peluzio, J. M., Afférri, F. S., Monteiro, F. J. F., Melo, A. V. de, \& Pimenta, R. S. (2010). Adaptability and stability of soybean cultivars under conditions of varzeas, in Tocantins State $\begin{array}{llll}\text { Brazil. Revista } \quad \text { Ciência 4gronômica, 41(3), } & \text { 427-434. }\end{array}$ https://doi.org/10.1590/S1806-66902010000300015

Pires, L. P. M., Pelúzio, J. M., Cancellier, L. L., Ribeiro, G. R., Colombo, G. A., \& Afférri, F. S. (2012). Desempenho de genótipos de soja, cultivados na região centro-sul do estado do Tocantins, safra 2009/2010. Bioscience Journal, 28(2), 214-223. http://www.seer.ufu.br/index.php/biosciencejournal/article/view/11682

Polizel, A. C., Juliatti, F. C., Hamawaki, O. T., Hamawaki, R. L., \& Guimarães, S. L. (2013) Adaptabilidade e estabilidade fenotípica de genótipos de soja no estado do Mato Grosso. $\begin{array}{lll}\text { Bioscience } \quad \text { Journal, } & \text { 910-920. }\end{array}$ http://www.seer.ufu.br/index.php/biosciencejournal/article/view/15079/12905

Rocha, R. B., Muro-Abad, J. I., Araújo, E. F., \& Cruz, C. D. (2005). Avaliação do método centróide para estudo de adaptabilidade ao ambiente de clones de Eucalyptus grandis. Ciência Florestal, 15(3), 255-266. https://doi.org/10.5902/198050981863

Sediyama, T., Silva, F. L., \& Borém, A. (2015). Soja do plantio a colheita. 1.ed. Viçosa-MG. UFV. 333p.

Silva, J. B., Lazarini, E., Silva, A. M., \& Reco, P. C. (2010). Ensaio comparativo de cultivares de soja em época convencional em Selvíria, ms: características agronômicas e produtividade. Bioscience Journal, 26(5), 747-754. http://www.seer.ufu.br/index.php/biosciencejournal/article/view/7186/5264

Silveira, D. A., Bahry, C. A., Pricinotto, L. F., Nardino, M., Carvalho, I. R. \& Souza, V. Q. de (2018). Adaptability and stability of grain yield in soybean. Australian Journal of Crop Science, 12(4), 717-725. https://doi.org/10.21475/ajcs.18.12.05.PNE821 


\section{Macrothink}

Silveira, D. A., Pricinotto, L. F., Nardino, M., Bahry, C. A., Prete, C. E. C. \& Cruz, L. (2016). Determination of the adaptability and stability of soybean cultivars in different locations and at different sowing times in Paraná state using the AMMI and Eberhart and Russel methods. Semina: Ciências $\quad$ Agrárias, $\quad 37(6), \quad 3973-3982$. https://doi.org/10.5433/1679-0359.2016v37n6p3973

Vasconcelos, E. S. de, Reis, M. S., Sediyama, T. \& Cruz, C. D. (2015). Produtividade de grãos, adaptabilidade e estabilidade de genótipos de soja de ciclos precoce e médio Grains productivity, adaptability and stability of earlier and medium cycles of soybean genotypes.

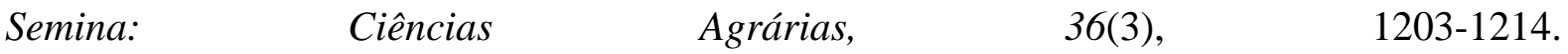
https://doi.org/10.5433/1679-0359.2015v36n3p1203

Yan, W., Hunt, L. A., Sheng, Q., \& Szlavnics, Z. (2000). Cultivar evaluation and mega-environment investigation based on GGE biplot. Crop Science, 40(3), 597-605. https://doi.org/10.2135/cropsci2000.403597x

Yokomizo, G. K-I., \& Santos, I. C. dos (2018). Desempenho de genótipos de soja no cerrado amapaense de 2009 a 2013. Amazonian Journal of Agricultural and Environmental Sciences, 61, 1-8. http://dx.doi.org/10.22491/rca.2018.2395

Yokomizo, G. K-I., Duarte, J. B., Vello, N. A., \& Unfried, J. R. (2013). Análise AMMI da produtividade de grãos em linhagens de soja selecionadas para resistência à ferrugem asiática. $\begin{array}{llll}\text { Pesquisa Agropecuária } & \text { Brasileira, } & \text { 48(10), }\end{array}$ https://doi.org/10.1590/S0100-204X2013001000009

Zanon, A. J., Silva, M. R., \& Tagliapietra, E. L. (2018). Ecofisiologia da soja visando altas produtividades. Santa Maria-RS. UFSM. 134p.

\section{Copyright Disclaimer}

Copyright for this article is retained by the author(s), with first publication rights granted to the journal.

This is an open-access article distributed under the terms and conditions of the Creative Commons Attribution license (http://creativecommons.org/licenses/by/4.0/). 